\title{
Co-Administration of Crude Ethanolic Leaf Extract of Ageratum conyzoides ameliorates Nigerian Bonnylight Crude Oil-Induced Erythrocyte Haemolysis in Female Wistar Rats
}

\author{
Ita, S. O., Nya, M. E \\ Department of Physiology, Faculty of Basic Medical Sciences, College of Health Sciences, University of Uyo, \\ Uyo, Akwalbom State, Nigeria.
}

\begin{abstract}
This study focused on the osmotic fragility of erythrocytes and its indices in rats treated with ethanolic leaf extract of Ageratum conyzoides following the administration of Nigerian Bonnylight crude oil (NBLCO). Twenty female Wistar rats (120-150g body weight) were divided into four groups of five rats each. The rats in group I served as the control group and was oral gavaged $3 \mathrm{ml} / \mathrm{kg}$ of normal saline; group II gavaged $748.33 \mathrm{mg} / \mathrm{kg}$ body weight of the extract of A. conyzoides, which was $20 \%$ of the $L D_{50}(3741.66 \mathrm{mg} / \mathrm{kg}$ ). Group III was gavaged 3ml/kg body weight of NBLCO. This dose was calculated as $20 \%$ of the lethal dose of $14.14 \mathrm{ml} / \mathrm{kg}$. Group IV animals were gavaged $748.33 \mathrm{mg} / \mathrm{kg}$ body weight of the extract of A. conyzoides, and $3 \mathrm{ml} / \mathrm{kg}$ body weight of NBLCO. In all cases, doses were applied daily for 31 days according to animal's most recent body weight. The results showed that NBLCO significantly increased osmotic fragility while reducing erythrocyte parameters and indices evaluated compared with control group (normal saline) and A. conyzoides group (group II) $(p<0.05)$. A. conyzoides supplementation helped in increasing these parameters significantly $(p<0.05)$. The results of this study provides evidence that NBLCO has a damaging effect on blood as it can negatively interfere with the functionality of the red blood cell membranes causing haemolysis and ultimately resulting in anaemia. The co-administration of ethanol leaf extract of $A$. conyzoides has the potential to mitigate this damaging effect of NBLCO to erythrocytes.
\end{abstract}

Keywords: Crude Oil, Erythrocyte Membrane, Erythrocyte Haemolysis, Osmotic Fragility, Ageratum conyzoides

\begin{abstract}
Abbreviations
Nigerian Bonnylight crude oil (NBLCO), Analysis of variance (ANOVA), Red blood cell (RBC), Packed cell volume (PCV), Haemoglobin (HGB), Mean corpuscular volume (MCV), Mean corpuscular haemoglobin $(\mathrm{MCH})$, Mean corpuscular haemoglobin concentration $(\mathrm{MCHC})$
\end{abstract}

\section{Introduction}

A measure of the capacity of red blood cells to resist osmotic stress defines its osmotic fragility index. Measurement of osmotic fragility of erythrocytes has found clinical usefulness for diagnostic purposes, particularly useful in the diagnosis of haemolytic diseases, studies of membrane permeability, and alterations leading to destruction of erythrocytes (Jain et al., 1983). The erythrocyte membrane is particularly vulnerable to toxicants in NBLCO ranging from heavy metals to polycyclic aromatic hydrocarbons. One important identifiable condition associated with shortage of blood is anaemia. Erythrocyte haemolysis among other causative factors is identified to be the cause of anaemia. And maintenance of integrity of erythrocyte is primarily the function of its membrane; the major components of the membrane are the proteins and lipids, where cholesterol play a vital role in the fluidity of erythrocyte membrane (Berg et al., 1998), and subjecting the membrane to peroxidation by oxidant radicals will not only reduce membrane fluidity but increase permeability of the membrane (van Ginkel and Sevanian, 1994). Many compounds exert considerable influence on the membrane integrity by direct chemical contact with biomolecules particularly the lipids and proteins that constitute the architectural structure of plasma membrane (Oteiza, 1994).

Widespread haemolysis can also cause electrolyte imbalance, more so, as the activity of the $\mathrm{Na}^{+}-\mathrm{K}^{+}$ ATPase pump is essential for the maintenance of electrolyte balance particularly $\mathrm{Na}^{+}$and $\mathrm{K}^{+}$across membranes of the cells including erythrocyte membrane (De Riva and Vircici, 1998) and by extension plays a vital role in maintenance of cell volume as well as maintaining high concentration of intracellular potassium (Mayne, 1994).

Perturbations of the erythrocyte membrane architectural assembly by exogenous insult such as cigarette smoking, carbon monoxide and polycyclic aromatic hydrocarbons lead to various altered membrane material properties and altered red blood cell behaviour in the circulation. Perturbation of membrane has been reported to affect membrane-associated cell-regulatory mechanisms which are essential for the survival and viability of the cell. Such alterations in turn are directly associated with changes in cellular deformability either as a result of 
increased membrane rigidity or decreased surface-area-to-volume ratio. Cellular deformability is one of the major parameters that determine red cell life span, and certain xenobiotic have been known to compromise the capacity of red blood cell to withstand osmotic stress (Ojoet al., 2006). Exposure to NBLCO has been reported to be injurious to erythrocyte membrane, and consequently cause haemolytic anaemia by destroying the membrane to facilitate hemolysis (Ita etal., 2011; Sunday et al., 2013).The search for a substance that will reduce or prevent such injuries to erythrocyte membrane will offered a solution to destruction of erythrocyte by NBLCO and thus prevent anaemia. Since petroleum products are lipophilic in biological membranes, this study was so designed with the aim of investigating the effects of ethanolic leaf extract of Ageratum conyzoides on Nigerian Bonnylight crude oil-induced red cell haemolysis.

\subsection{Crude petroleum}

\section{Materials And Methods}

The crude petroleum used in this study was obtained from the Exxon Mobil laboratory, Ibeno, Nigeria.

\subsection{Collection of plant material}

The whole plant was obtained from the Botanical farm of the Department of Pharmacognosy and Natural Medicine, University of Uyo, Uyo, Nigeria. Specimen of the leaves was authenticated by Dr. (Mrs.) Uduak Aniema Essiett of the Department of Botany and Ecological Studies, University of Uyo, Uyo. A voucher specimen (UUH 3517) was deposited at the Herbarium.

\subsubsection{Preparation of leave extract}

The leaves of A. conyzoides were rinsed with distilled water and dried under shade. The dried leaves were ground into powder with an electric blender. Four hundred grammes of the blended leaves sample was macerated in $700 \mathrm{ml} 70 \%$ ethanol, agitated for 10 minutes with an electric blender and left overnight in a refrigerator at $4^{\circ} \mathrm{C}$. The mixture was filtered with a cheese cloth and the filtrate obtained concentrated under reduced pressure using a rotary evaporator $\left(a t 37^{\circ} \mathrm{C}\right.$ ) to about $10 \%$ of its original volume. The concentrate was then allowed in a water bath at $37^{\circ} \mathrm{C}$ for complete evaporation to dryness yielding $40.64 \mathrm{~g}(17.5 \%)$ of the extract.

\subsubsection{Acute toxicity test}

Acute toxicity study $\left(\mathrm{LD}_{50}\right)$ was estimated using Lorke's method (Lorke, 1993). A total of 25 mice weighing between 15-22g were divided into five groups with five mice per group. Mice in the five groups were administered $3000 \mathrm{mg} / \mathrm{kg}, 3500 \mathrm{mg} / \mathrm{kg}, 4000 \mathrm{mg} / \mathrm{kg}, 4500 \mathrm{mg} / \mathrm{kg}$ and $5000 \mathrm{ml} / \mathrm{kg}$ of body weight respectively (intraperitoneally). All experimental animals were observed for physical signs of toxicity such as gasping, palpitation, writhing, decreased respiratory rate, body limb and death after 24 hours.

The median lethal dose of Ageratum conyzoides was calculated as geometrical means of the maximum (most tolerable) dose producing $0 \%$ mortality (a) and the minimum (least tolerable) dose producing $100 \%$ mortality (b) using the formula:

$$
\begin{aligned}
\mathrm{LD}_{50} & =\sqrt{ } \mathrm{ab} \\
\mathrm{LD}_{50} & =\sqrt{ } 3500 \times 4000 \\
& =3741.66 \mathrm{mg} / \mathrm{kg}
\end{aligned}
$$

The acute toxicity test for the NBLCO also involved 25 mice weighing between 15-22g were divided into five groups with five mice per group. Mice in the five groups were administered intraperitoneally $10 \mathrm{ml} / \mathrm{kg}, 15 \mathrm{ml} / \mathrm{kg}$, $20 \mathrm{ml} / \mathrm{kg}, 25 \mathrm{ml} / \mathrm{kg}$ and $30 \mathrm{ml} / \mathrm{kg}$ of body weight respectively.

$$
\begin{aligned}
\mathrm{LD}_{50} & =\sqrt{ } 10 \times 20 \\
& =14.14 \mathrm{ml} / \mathrm{kg}
\end{aligned}
$$

\subsection{Experimental animals}

Female Albino Wistar rats weighing between 150-180g were obtained from the Animal House of the Faculty of Basic Medical Sciences University of Uyo,Uyo, Nigeria and were kept in a well-ventilated section of the Animal House. They were allowed access to feed (Chow: vital feeds, Grand Cereals Ltd, Jos) and water adlibitum. The animals were kept in separate experimental room and allowed to acclimatize for a period of one week before commencement of studies. 


\subsection{Experimental design and treatment of animals}

A total of twenty (20) adult female Albino Wistar rats were randomly divided into four groups (group I, II, III and IV) of five (5) rats each. Group I served as the control and was oral gavaged $3 \mathrm{ml} / \mathrm{kg}$ body weight of normal saline. Group II was oral gavaged $748.33 \mathrm{mg} / \mathrm{kg}$ body weight of ethanolic leaf extract of Ageratum conyzoides, this dose was calculated as $20 \%$ of the lethal dose $\left(\mathrm{LD}_{50}\right)$ of $3741.66 \mathrm{mg} / \mathrm{kg}$. Group III was oral gavaged $3 \mathrm{ml} / \mathrm{kg}$ body weight of NBLCO. This dose was calculated as $20 \%$ of the lethal dose $\left(\mathrm{LD}_{50}\right)$ of 14.14 $\mathrm{ml} / \mathrm{kg}$, while group IV in addition to $3 \mathrm{ml} / \mathrm{kg}$ body weight of NBLCO, were supplemented with $748.33 \mathrm{ml} / \mathrm{kg}$ body weight of ethanolic leaf extract of Ageratum conyzoides. In all cases, the doses were based on the rat's most recently recorded body weight. The calculated volume in milliliter $(\mathrm{ml})$ was applied daily for thirty one (31) days. The experimental procedures involving the animals and their care were conducted in conformity with the approved guidelines by the Research and Ethical Committee of the Faculty of Basic Medical Sciences, University of Uyo, Uyo. Nigeria.

\subsection{Collection of blood sample for analysis}

After thirty one (31) days of administration, the rats were anaesthetized with chloroform soaked in swap of cotton wool in a killing chamber. A $(5 \mathrm{ml})$ sterile syringe with needle was used for collection of blood from the heart, by a process known as cardiac puncture. The total volume of blood collected was $4 \mathrm{ml}$, which was divided into two portions, one portion was transferred into properly labeled, heparinized sample bottles for osmotic fragility test. The animals were sacrificed in two batches since osmotic fragility test is required to be done within six hours of sample collection. The second portion was transferred into EDTA sample bottles and use for determination of haematological parameters.

\subsection{Determination of osmotic fragility}

Digital chemical balance was used to weigh $18 \mathrm{~g}$ of sodium chloride $(\mathrm{NaCl}), 2.731 \mathrm{~g}$ of sodium hydrogen phosphate $\left(\mathrm{Na}_{2} \mathrm{HPO}_{4}\right)$ and $0.486 \mathrm{~g}$ of sodium hydrogen phosphate $\left(\mathrm{NaH}_{2} \mathrm{PO}_{4} \cdot 2 \mathrm{H}_{2} \mathrm{O}\right)$. The salts were dissolved in $1000 \mathrm{ml}(1 \mathrm{~L})$ of de-ionized water and stirred with a glass rod stirrer to give a homogenous $10 \%$ stock solution of $\mathrm{NaCl}$. The stock solution was stored in a bottle with a stopper. Twelve test tubes were labeled 0.1- 0.9(normal saline). From the stock saline solution above, a serial dilution with deionized water was done to obtain the various test concentrations ranging from $0.10 \mathrm{~g} / \mathrm{dL}-0.9 \mathrm{~g} / \mathrm{dL}$.

2.6.1Procedure: Osmotic fragility of the erythrocytes was determined by pipetting $4 \mathrm{ml}$ of $\mathrm{NaCl}$ saline of serial concentrations ranging from $0.1-0.9 \%$ saline into twelve well labeled test tubes, and thereafter 2 drops of blood sample were added to each test tube. The tubes were capped with the thumb finger, and inverted several times. The mixtures were allowed to stand for $30 \mathrm{mins}$ at room temperature $\left(25^{\circ} \mathrm{C}\right)$ and then centrifuged at $3000 \mathrm{rmp}$ for 5 minutes. The supernatant was decanted and its haemoglobin content was determined spectrophotometrically at a wave length of 540nm. The percentage haemolysis in each concentration of buffered saline was calculated assuming $100 \%$ haemolysis in the concentration with the highest absorbance.

2.7 Determination of haematological parameters: The blood sample in the EDTA sample bottles were used for the determination of erythrocyte count, packed cell volume (PCV) and haemoglobin (Hb) concentration with the aid of an automatic haematology analyzer (MindrayHematologyanalyzer, BC-2300).

\subsection{Statistical analysis}

Data were expressed as the mean \pm standard error of the mean. Statistical analysis was carried out using window SPSS package (SPSS 22.00 version). Data were analyzed using one way analysis of variance (ANOVA), results obtained were further subjected to test for least significant difference (LSD). Values of $\mathrm{P}<0.05$ were considered significant.

\subsection{Erythrocyte osmotic fragility}

\section{Results}

As would be observed in figure 1, NBLCO ingestion significantly increased erythrocyte haemolysis with respect to groups I and II (the control and A. conyzoides groups respectively) ( $\mathrm{p}<0.05)$. Co-administration of $A$. conyzoides to group IV animals significantly increased erythrocyte resistance to haemolysis with respect to NBLCO-treated group (group III) $(\mathrm{p}<0.05)$. 


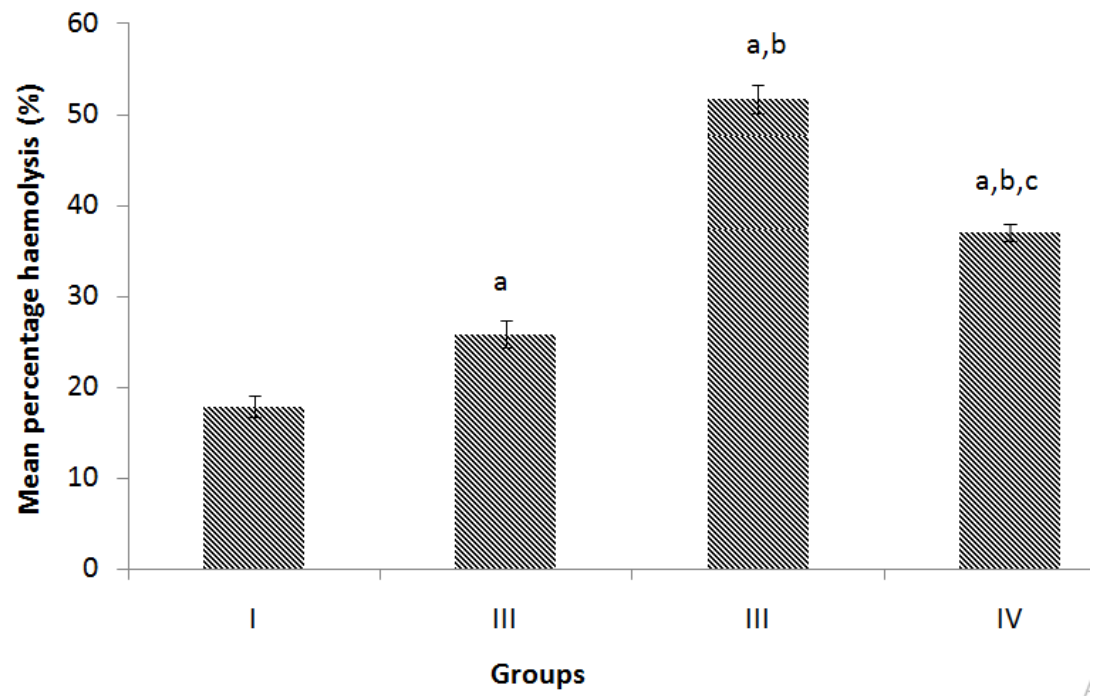

Figure 1: Comparing the degree of osmotic fragility in the various groups. Values are mean \pm SEM. $a=p<0.05$ vs group I, $b=p<0.05$ vs group II, $c=p<0.05$ vs group III

\subsection{Erythrocyte parameters}

The results of the mean values of the RBC, PCV, $\mathrm{HGB}, \mathrm{MCV}, \mathrm{MCH}$ and $\mathrm{MCHC}$ obtained in this study are shown on table 1. As would be observed, ingestion of NBLCO significantly decreased RBC with respect to groups I and II (the control and A. conyzoides groups respectively) $(\mathrm{p}<0.05)$. The crude oil administration although recorded marginal reductions in $\mathrm{PCV}, \mathrm{HGB}, \mathrm{MCH}$, and $\mathrm{MCHC}$, which were however not significantly different from groups I and II, it significantly reduced MCV with respect to group I $(\mathrm{p}<0.05)$ but was not significantly different from group II (A. conyzoides group). Co-administration of A. conyzoides to group IV animals increased RBC to value that was significantly higher than NBLCO group III $(\mathrm{p}<0.0 \%)$ but not significantly different from groups I and II. The co-administration of Ageratum conyzoides with NBLCO did not alter significantly the values of $\mathrm{PCV}, \mathrm{HBG}, \mathrm{MCV}, \mathrm{MCH}$, and $\mathrm{MCHC}$ with respect to groups I and II.

Table 1.Comparison of erythrocyte parameters and indices in rats following exposure to NBLCO and ethanolic leaf extract of Ageratumconyzoides for 31 days.

\begin{tabular}{|l|l|l|l|l|l|l|}
\hline Groups & RBC $\left(\times 10^{6} \mu \mathrm{L}\right)$ & HGB $(\mathrm{g} / \mathrm{dL})$ & PCV $(\%)$ & MCV $(\mathrm{pg} / \mathrm{dL})$ & $\mathrm{MCH}(\mathrm{fL})$ & $\mathrm{MCHC}(\mathrm{g} / \mathrm{dL})$ \\
\hline I & $8.10 \pm 0.26$ & $13.97 \pm 0.12$ & $42.67 \pm 1.20$ & $47.50 \pm 1.26$ & $18.03 \pm 0.12$ & $35.50 \pm 1.09$ \\
\hline II & $8.02 \pm 0.34$ & $14.78 \pm 0.20$ & $44.00 \pm 1.06$ & $40.33 \pm 1.28$ & $17.48 \pm 0.65$ & $32.00 \pm 1.36$ \\
\hline III & $5.12 \pm 0.31 \mathrm{a}, \mathrm{b}$ & $11.95 \pm 0.36$ & $31.00 \pm 1.93$ & $26.83 \pm 1.89$ & $14.45 \pm 0.58 \mathrm{a}$ & $23.53 \pm 1.54$ \\
\hline IV & $7.12 \pm 0.48 \mathrm{a}, \mathrm{b}, \mathrm{c}$ & $13.58 \pm 0.21$ & $44.50 \pm 1.52$ & $36.83 \pm 1.98$ & $17.57 \pm 0.36$ & $29.57 \pm 0.74$ \\
\hline
\end{tabular}

Legend:

$\mathrm{a}=$ significantly different from group I $(\mathrm{p}<0.05)$

$\mathrm{b}=$ significantly different from group II $(\mathrm{p}<0.05)$

$\mathrm{c}=$ significantly different from group III $(\mathrm{p}<0.05)$

\section{Discussion}

The results of this study have shown that ingestion of NBLCO by female Wistar rats cause haemolysis by reducing the resistant capacity of the erythrocytes against hypotonic solution. The NBLCO did not only increase the osmotic fragility of erythrocyte but cause significant reduction in erythrocyte parameters and indices. . Increased red blood cell fragility as reported in this study can be considered a good indicator of Nigerian Bonnylight crude oil toxicity in rats. These results collaborates the available information in literature that NBLCO could induce anaemia by its haemolytic activity on erythrocyte (Ita et al., 2011; Ita et al., 2013). Massive blood cell destruction in birds following crude oil ingestion has also been reported (Suzanne, 2003; Becki, 2007). The sum total of such massive unmitigated red blood cell destruction (haemolysis) could lead to anaemia, which Suzanne (2003) proposed to be as a result of oxidant chemical damage to haemoglobin. Negative changes in erythrocyte fragility along with negative changes in other haematological parameters and indices as reported in this study could affect the health and performance of animals, the major effect been alteration in normal erythrocyte integrity and membrane stability, increased erythrocyte haemolytic activities, decreased haemoglobin and ultimately resulting in anaemia. The results in this study completely agree with previous claimed by Uwake and Ezeh (2000), Ali and Kadaru (2005) that xenobiotics have the capacity to 
interfere with red blood cell membrane integrity and stability. What appeared to be the common decimal in the membrane destabilization by xenobiotics including NBLCO is their ability to generate high levels of free radicals (Chikezie et al, 2009), which can ultimately overwhelm the capacity of the endogenous antioxidant defense systems to maintain and sustain membrane integrity.

The obvious reduction recorded for RBC, PCV and HGB can be said to suggest crude oil-induced anaemia. Many researchers in this field have reported that crude oil or its various constituents have demonstrated anaemic potency in experimental animals by reduction in two or all of RBC, PCV and HGB (Leighton, 1990; Ovuru and Ekweozor, 2004; Eyong et al, 2004). In fact Degowin et al (1989) have reported that benzene, one important constituent of crude oil can suppress erythropoietic activity by activating the production of prostaglandins $\left(\mathrm{PGE}_{2}\right)$. NBLCO can cause a whole lot of damage to the red cell membrane via generation of ROS and lipid peroxidation that make the cell to be more susceptible to lysis and promote oxidation of HGB to reduce its concentration. But the co-administration of leaf extract of A. conyzoides significantly reversed the situation by reducing the fragility as well as raising the erythrocyte parameters.

\section{Conclusion}

The results of this study provides evidence that NBLCO has a damaging effect on blood as it can negatively interfere with the functionality of the red blood cell membranes causing haemolysis and ultimately resulting in anaemia. The co-administration of ethanol leaf extract of $A$. conyzoides has the potential to mitigate this damaging effect of NBLCO to erythrocytes.

\section{Reference}

[1]. Ali, M. S. M. and Kadaru, A. G. M., 2005. In vitro processing of donor blood with sulphadoxine-pyrimethamine for eradication of transfusion-induced malaria. American Journal of Tropical Medicine and Hygiene,73(6): 1119-1123.

[2]. Becki, L., 2007. General chemical information and Toxicity of crudepetroleum. Chemicals, 26:6-19.

[3]. Berg, J. M., Tymoczko, J. L. and Stryer, L., 1998. Biochemistry. New York: Freeman \& Company. p. 289.

[4]. Chikezie, P. C., Uwakwe, A. A. and Monago, C. C., 2009. Studies of human HbAA erythrocyte osmotic fragility index of nonmalarious blood in the presence of five antimalarial drugs. Journal of Cell and Animal Biology, 3(3): 39-43.

[5]. Degowin, R., Fisher, P. and An, D., 1987. Differential elaboration of Prostaglandin $E_{2}$ by cells of the hemopoietic microenvironment in response to endotoxin. Journal Laboratory Clinical Medicine, 109:679-686.

[6]. De Riva, C. and Vircici, E., 1998. Impaired $\mathrm{Na}^{+}-\mathrm{K}^{+}$ATPase activity in red blood cells in euthyroid women treated with levothyroxine after total thyroidectomy for Graves' disease. Metabolism, 47(10):194-198.

[7]. Eyong, E. U., Umoh, I. B., Ebong, P. E. Eteng, M. U. Antai, A. B. and Akpa, A. O.,2004. Haematoxic effects following ingestion of Nigerian crude oil and crude oil polluted shellfish by rats. Nigerian Journal of Physiological Sciences, 19(1-2):1-6.

[8]. Ita, S. O., Udofia, U. A., Udokang, N. E. and Okon, U. A., 2011. Comparative osmotic fragility in rats following ingestion of crude oil (Nigerian Bonny Light), petrol, kerosene and diesel. Inter J Curr Trends Sci Tech., 2(7):326-331.

[9]. Ita, S. O., Aluko, E. O., Atang, D. E., Antai, A. B. and Osim, E. E., 2013. Vitamin C or E Supplementation Ameliorates Nigerian Bonny Light Crude Oil-induced Erythrocyte Haemolysis in Male Wistar Rats. Biochemistry \& Molecular Biology, 1(3):44-51

[10]. Jain, S. K. Mohandas, N., Clark, M. R. and Shobel, S. B., 1983. The effect of MDA, a product of lipid peroxidation on the deformability, dehydration and ${ }^{51} \mathrm{Cr}$ survival of erythrocytes. British Journal of Haematology, 53:247-252.

[11]. Leighton, F. A., 1990. The systemic toxicity of Prudhoe Bay crude and other petroleum oil to CD-1 mice. Archieve of Environmental Contamination and Toxicology, 19:257-262.

[12]. Lorke, D., 1982. A New Approach to Practical Acute Toxicity Testing. Arch Toxicol., 54:275-287.

[13]. Mayne, P. D., 1994. Sodium, water and potassium metabolism. In: Clinical chemistry in diagnosis and treatment. Mayne, P. D. editor. $6^{\text {th }}$ ed. London: Edward Arnold; p. 25-78.

[14]. Ojo, O. O., Kabutu, F. R.., Bell, M. and Babayo, U., 2006. Inhibition of paracetamol induced oxidative stress in rats by extract of Cymbopogoncitracus (green tera). African Journalof Biotechnology, 5:12

[15]. Oteiza, P. A., 1994. A mechanism for the stimulatory effect of aluminum on iron-induced lipid peroxidation. Archieves of Biochemistry and Biophysics. 308(2):374-379.

[16]. Ovuru, S. S. and Ekweozor, I. K. E. 2004. Haematological changes associated with crude oil ingestion in experimental rabbits. African Journal of Biotechnology, 3(6):346-348.

[17]. Suzanne, I. B., 2003: Therapeutic and nutritional information on crude oil. Chemicals 6:4-11.

[18]. Uwakwe, A. A. and Ezeh, S. O., 2000. Effect of aqueous extracts of some medicinal herbs on haemoglobin S gelation, erythrocyte sickling and osmotic fragility. International conference on sickle cell disease and Environmental sickling Agents. Sickle cell Research and Awareness Group (SCRAG Incoporated).P. 32

[19]. Van Ginkel, G. and Sevanian, A., 1994. Lipid peroxidation induced membrane structural alterations. Methods Enzymol. 233:273-288. 